\title{
Rediscovered: Two Short Stories by Edith Searle Grossmann
}

\author{
Rebecca Burns
}

\section{INTRODUCTION}

In 1893, Edith Searle Grossmann (1863-1931) published her second novel, In Revolt. Appearing at the cusp of the New Woman phenomenon, In Revolt marked Grossmann's keen interest in the women's movement of the late nineteenth century. The novel portrayed, in unflinching detail, the powerlessness of unhappily married, uneducated women; noting the novel's strident tone, modern-day critics have regarded the text as voicing Grossmann's 'feminist protest [...against] the evils of male domination' (Moffat). Despite In Revolt's political urgency, it took another fourteen years for Grossmann to publish its sequel; Knight of the Holy Ghost appeared in 1907 whilst Grossmann was living in London (the novel was republished in 1908 as Hermione: A Knight of the Holy Ghost), and detailed the experiences of Hermione Carlisle after escaping her abusive husband. The birth of Grossmann's son and an extended trip to London may have had an impact upon her productivity ${ }^{1}$. Yet a search of the Papers Past (online) database reveals that the years between 1893 and 1907 were not, in terms of fictional output, completely barren for Grossmann. In fact, alongside the many descriptive and polemical newspaper articles she produced, Grossmann also published two short stories, both in the Otago Witness. 'The Twin Brides of Waitotara' appeared on 24 June 1897 and 'My Little Boy' on 2 Feb 1899. This essay offers the first critical readings of these stories, and considers their place in the trajectory of Grossmann's body of work as a whole. The stories' subject matter, religiosity, employment of certain symbols and motifs, and weaving of New Woman themes throughout the narratives - also to be found in her novels - make the stories worthy of further consideration.

\section{'THE TWIN BRIDES OF WAITOTARA'}

Given the unlikelihood of readers of Grossmann's novels being familiar with 'The Twin Brides of Waitotara' (hereafter 'Twins') and 'My Little Boy' 
(hereafter 'Boy'), critical analysis of the stories will be prefaced with a brief description of the plot. Appearing in the Otago Witness in $1897^{2}$, 'Twins' portrays the lives of Jessie and Margaret (Meg) McGregor, twin sisters living with their parents in an isolated cottage in the New Zealand bush. We meet the sisters at the moment they decide whether to commit to their lovers, both about to leave for India for three years. Jessie is unable to promise herself to Robert Tressilian, stating she is afraid of the lengthy wait ahead. Meg does pledge herself, however, to Philip Lewin and, despite the opposition of her parents and 'her father's threatened horse-whip' ('Twins') when he hears of the union, she remains steadfast in her determination to leave New Zealand and join Lewin in India. She also overcomes the interference of the local minister, who attempts to yoke her back under parental control with his words about 'the sin of filial disobedience, of self-will and self-indulgence' ('Twins'). Eventually her determination wins out and she sails for India, leaving Jessie alone with her parents.

Missing her sister, with whom she had 'slept, toiled, and prayed' ('Twins'), Jessie is invigorated by Meg's letters describing married life in a new land. As a surprise, Meg arranges for Jessie's rejected sweetheart, Robert Tressilian, to take Jessie her old wedding veil, a 'prophecy' ('Twins') of Jessie's marriage to come. Invited into the McGregor's home, Robert realises that 'life stood still' ('Twins') in the colony, and that Jessie is also in danger of becoming trapped within such a vacuum. He asks her to marry him; they do, with Jessie wearing Meg's veil, and they travel to India where Jessie is reunited with her sister. The story does not quite end there, however. Instead, it concludes with a self-aware narrative interjection; the narrator refers to the demand that 'modern story-tellers are forbidden to end with weddings and golden prospects' ('Twins') and, with a deliberation that reveals the constructed fabric of the tale, the narrator goes on to note that life did not run smoothly in India for the McGregor sisters. Indeed, 'they wearied of heat and leisure and luxury, and Jessie's first baby died' ('Twins'). Regardless, they continued to think of their New Zealand home with fondness and romanticised it from afar.

The effect of concluding the story in such a way - with a reference to a discursive framework shaping the text - is to draw attention to the literary and social contexts within which 'Twins' was written, and signals the author's self-aware engagement with current literary trends. One of the most discussed and controversial of literary developments at that time - 
both in published fiction and in the popular press - was the rise of the New Woman, and Grossmann's story appeared during an intensely active period for New Woman writing. Sally Ledger has observed that '[w]oman's role variously as a wife, a mother and a sexual subject were all under scrutiny in the debates on the New Woman at the fin de siècle' (156); 'Twins' forms part of that debate by addressing marriage, which was a recurrent and problematic issue for New Women writers. From the moment Sarah Grand concluded 'The New Aspect of the Woman Question' - the essay from which the New Woman phenomenon took its name - with the comment that 'The Woman Question is the Marriage Question' (146), late nineteenth-century literary women reassessed, in print, the merits and conditions of marriage. Although New Women writers 'shared no single idea about the institution' (Christensen Nelson, Fiction Writers 41), they all agreed that

marriage was in need of reform and that social reform and marital reform must proceed together, since the adverse social and economic conditions for women at the time directly affected the conditions of marriage. (41).

In 'Twins', Grossmann contemplates the issue of marriage by portraying and also undermining the social restrictions framing the entanglements of late-Victorian women. This is evident, for example, in the scene in which Jessie rejects Robert Tressilian. Sitting with him just before he leaves for India, she demurely pulls her apron up, 'hiding her face' ('Twins') as Robert asks for her promise. Jessie is unwilling to pledge herself to him:

'I can’t promise, Rob. Three years! I am afraid.'

'Afraid, Jessie? Of what?'

'Of everything - of myself; of father and mother; and,' sinking her voice like a child, 'of God.' ('Twins').

Here, Jessie's response and behaviour is codified and circumscribed by the trinity of self-control ('myself'), parental regard ('father and mother') and morality ('God'). These were regularising impulses against which New Women fought, sharing, as they did, 'a rejection of the culturally defined feminine role' (Christensen Nelson, 'Introduction', $\mathrm{x}$ ) and a desire to 'challenge[...] prevailing socio-cultural definitions of femininity and masculinity' (Lovell, qtd. in Pykett 14). Thus Grossmann registers these regularising forces, and then goes on to challenge them by employing the metaphor of the twin. Such a useful motif to a writer, the twin is suggestive 
of both mirror and difference. Physically, the McGregor sisters 'were wonderfully alike' ('Twins') but set apart in temperament: '[b]oth habitually kept their eyes upon the ground, a habit acquired in the domestic storms of their childhood, but at times Margaret lifted hers fully, and produced an instantaneous effect.' ('Twins'). Jessie, then, conforms to social expectations and adopts the demure stance of the archetypal Victorian woman, whilst Meg is positioned as the daring sister, shaking off the restraints of family and society, and accepting Lewin's proposal.

Meg has taken the step that her sister was afraid of, and, against the 'furious outbursts' ('Twins') of her father, holds firm in her promise to Lewin. Her unwillingness to bend therefore places her outside the sphere of the staid, reticent, 'maidenly' ('Truth', qtd. in Marks 3) Victorian woman. The transgressive nature of this act is implied through the symbol of the coloured rose; before parting with their lovers, Meg places 'a crimson flower' ('Twins') in her breast, marking herself out - in society's eyes - as no longer pure, whilst Jessie gives a white rose to Robert Tressilian, thus indicating her still-virginal state.

It is important to note, however, that Meg places the red rose in her own breast. Although Grossmann is more reticent in her fiction about women's sexuality than other New Women writers, such as George Egerton ${ }^{3}$, the New Woman was, as Gail Cunningham points out, generally 'regarded as a highly sexual being' (14). This was ostensibly because of the New Woman desire to examine and challenge society's grip on sexual expression and the resultant codification and control of women's bodies. Thus, in placing a red rose in her dress, Meg ironically acknowledges society's view of her as no longer pure, but also takes ownership of her sexuality.

Such a fresh, feminist appropriation of symbolic meaning recurs in 'Twins' and elsewhere in Grossmann's writing, particularly in relation to her interpretative use of Christian imagery. For example, just before their promise of marriage is sealed with their first kiss, Meg and Lewin pray together:

They knelt down together on a stone, and she prayed a few words that will not bear repetition, her lips firm and her brow ecstatic. Then, standing up, they embraced and took their first kiss. She pointed to the cloud, and said in an awe-struck whisper:

'Look Philip! It is like the pillar of cloud by day and fire by night. It goes with you.' ('Twins'). 
Grossmann's reference to the pillars of cloud and fire, with its clear allusion to Moses leading the Israelites from Egypt to the promised land (Exodus 13:21-22), is a kind of double metaphor. On the one hand, the allusion infuses the New Zealand landscape with powerful religiosity, drawing the environment out as a site of hope and agency in stark contrast to Meg's 'dark and cold' home ('Twins') from which Lewin's proposal offers an escape. In this interpretation, the landscape is celebrated as a metaphor for change: 'The steep path, the dark shade, the mass of rolling cloud and the fervent blue were full of fateful significance to [Meg's] frame of mind.' On the other hand, it is also possible to see the allusion between New Zealand and Exodus as Grossmann's attempt to empty the biblical image of its remote, distant authority and compress within the relations between a man and woman. For example, Meg appropriates the symbols from Exodus into her personal narrative, thus sanctioning her promised union with Lewin. This interpretation subverts the control of the Church in 'Twins' and uses biblical language and imagery as a Christian validation of a feminist agenda.

We see this particular kind of appropriation occur again in Meg's handling of the local minister, an old friend of her father's, who implores her to 'obey your parents [and reject Lewin]; you will forget this in time.' ('Twins'). In response,

Meg lifted her eyes to the summit, where the mist still lingered.

'We knelt down there together on the stone,' she said, 'and we called God to witness no one in this world - not father, nor mother, nor any friend - should ever part us till death.'

The minister looked on the ground and said no more. ('Twins').

By elevating the discussion to this spiritual level and appealing to a higher authority, Meg subverts the position of the minister and again reinterprets Christian sentiment to fit her own purpose. The purity of her resolve is irreproachable and forces the old minister into silence. Thus, whilst Jessie was controlled by her fear of parental and social disapproval, Meg validates her decision to marry Lewin through religious discourse.

It is interesting to consider the appropriation of biblical imagery in 'Twins' with Grossmann's novel, In Revolt, published three years earlier. In Revolt contains sections also querying the covenants governing women's lives, indicating that Grossmann was preoccupied with this debate and that 'Twins' might be positioned within the thematic continuum arcing Grossmann's work. For example, in the chapter entitled 
'The Holy Estate of Matrimony', Hermione Howard seeks pre-marital advice from Mr Howe, a minister and old friend of her father. He stresses 'the religious nature of her [marital] contract' (112) and that 'as a helpmate to a man was woman created [...] in all things you must submit yourself to your husband' (113). It is this socially prescribed submission of female will that Grossmann challenges most vociferously; Hermione bitterly condemns the status quo that gave her husband 'the right to torture her at his brutal will, the right confirmed by law, sanctified by Scripture, and applauded by society. (387, italics as in text).

\section{'MY LiTTLE BOY'}

Grossmann continued to dwell upon the issue of Christian authority over women in her short story 'My Little Boy', published on February $2^{\text {nd }}, 1899$ in the Otago Witness. Ostensibly, the story is a melodramatic work of fiction that tells the tale of a mother separated from her young son following a shipwreck, her refusal to believe he had drowned and her search for him, and their eventual reunion. However, it is also an allegory of hope, determination and rebirth and, like 'Twins', portrays a woman challenging biblical authority. It begins with Mary, who is emigrating with her son, Godfrey, from an unknown land (though references to 'magnolia' and 'cedar' trees hint at her home being in England), following the death of her husband. Sitting on the deck of an emigrant ship, Mary abandons her reading to appreciate the 'sultry afternoon' ('Boy') whilst Godfrey plays beside her. A 'gathering bank of grey cloud' ('Boy') threatens on the horizon; this and the oppressive atmosphere hints, in a meteorological and metaphorical sense, at the uneasy calm of the opening scene. Mary is caught in a liminal moment, between her old life and new; as she observes the flatness of the sea, 'smooth and blue [...] oppressed with some heavy spell' ('Boy'), Mary occupies a fluid, borderless space - up ahead, somewhere, is land, though at present she floats uncertainly. The moment is bracketed by a hopeful future and a miserable past; Mary is alone with her son following her husband's disgrace and subsequent suicide. 'Shot through the brain by his own hand, to save himself from shame and ruin' ('Boy'), the suggestion is that the death of Mary's husband and his unspoken crime have propelled Mary and her son onto the emigrant ship and out into this new, borderless environment. As the ship drifts on - as yet untouched by the storm - Mary's thoughts turn to her child, revealing the intense bond between the two: 
I thought of all my dreadful life lying behind in the few short years that had made me wife, mother, and widow, had showered on me all the sweetest gifts of life, and then had torn them from me, out of my very heart. All but my little Godfrey, the one little face to be a flower in my wilderness, the baby voice to be the one music in the world that did not break my heart with recollection. ('Boy').

A storm soon overtakes the ship, however, separating mother and son. Sitting in different life boats, Mary's vessel makes it ashore; she sees Godfrey's boat 'drift, keel upwards' ('Boy') and then disappear beneath the waves. Her fellow survivors believe that, like the others in the boat, Godfrey has drowned; Mary, however, is visited at night by her son in spirit form and believes fervently that he survived:

when I was sleeping my little boy came back to me and told me he had promised - as he had one day - not to die before me, for he meant to grow up and take care of me. But I must come, he said, and look for him, for he could not come himself. I asked where I should go, but I could not see him any more. It was not a seraph nor a vision; it was my own little son that I saw. ('Boy').

Motivated by her dreams, Mary searches the towns and surrounding area for her son, shrugging off the concerns of friends and relatives who felt she was losing her grip on reality and becoming 'crazed' ('Boy') by her loss. In particular, Mary resists the admonishment of her cousin, who approaches her as the voice of religious authority:

He was a very good man - very prominent in the Wesleyan Church - but he did not understand. 'Mary,' he said one day, 'it is just idolatry on your part. Godfrey has been taken from you because you worshipped him alone. You would not like to bring him back from heaven, would you?' I only told him there was no heaven for one of us without the other,' and I went on searching. ('Boy').

Soon after, Mary discovers that Godfrey had been rescued from the sea by a Maori couple and they are reunited. She learns that a Maori had rescued Godfrey from the sea and that 'the child had called [for Mary] in his sleep night by night.' ('Boy'). When friends congratulate her on finding Godfrey, Mary refers to the convictions which served her well: " "I knew I should see him again because his angel had promised me.” ' (Boy').

Death and resurrection motifs reoccur worldwide, in a variety of belief systems, historical myths and works of fiction. In her story, Grossmann alludes to importance of such motifs to Christianity through her evocative choice of character names; "Mary" and "Godfrey". Godfrey, the (S)son and 
allegorical Christ, is presumed to have died; Mary (sharing her name with the mother of Christ), is constant in her faith that he would return. Godfrey's subsequent discovery and resurrection is affirmed in the scene where he is reunited with his mother. Mary is in the company of her cousin, a lighthouse keeper and the Maori who rescued Godfrey from the sea. Holding her son and looking up at them, Mary believes them momentarily 'glorified into angels' ('Boy'); a description reminiscent of the biblical passage in Luke, where women visiting Jesus' tomb '[a]nd when they found not his body, they came, saying, that they had also seen a vision of angels, which said that he was alive.' (King James Bible, Luke 24. 23). Such allusions to scripture validate Mary's self-belief in searching for her son, and authorises her rejection of the dictates of a society seeking to control her behaviour - a society who would have her believe Godfrey had drowned.

In employing such biblical references, Grossmann was part of the collection of late-nineteenth-century women writers using fiction to 'inject their opinions on religious experience into the public arena.' (Christensen Nelson, Fiction Writers 59). As a New Woman, however, Grossmann's allusions to scripture when Mary is reunited with her son and her determined rejection of a controlling, ministerial presence is evocative of Olive Schreiner ${ }^{4}$, who was also a writer of religious, allegorical prose (Heilmann, passim). Schreiner's collection of allegories, Dreams (1890), used religious discourse to question the social infrastructures perpetuating the dominance over and marginalisation of women, and encouraged solidarity and support between the female sex. Ann Heilmann argues that it was the text's emphasis on female sacrifice that 'electrified most of [Schreiner's] contemporaries' for it 'lent universal significance to the personal and political aspirations of her readers' (125). A search of the Papers Past database uncovers attendant reports which reveal that Grossmann was both aware and an admirer of Schreiner. For example, in 1894, the Otago Witness carried another of Grossmann's articles - 'Spare Half-Hours: Genius and Talent in the Colony' - in which the author compared the English literary scene with that in the colonies. She concluded that English writers had become thematically stale:

[i]t is from the new literary nations [...] from the colonies themselves - that real creative force comes now [...]. It is [...] the works of Tolstoi, Turgenieff, Ibsen, Bjornsen, Olive Schreiner that open up fresh ground. (Emphasis added). 
Grossmann, then, may have been one of Heilmann's 'electrified readers' who recognised the power of Schreiner's allegories of female forfeiture and stoicism.

In 'My Little Boy', Grossmann authorises Mary's rejection of society's control through Christian symbols. For example, Mary's Wesleyan cousin is a metaphor for patriarchal dominance, yet she refuses to adhere to his admonishment and instead puts her faith in Godfrey's 'angel'. This further Christian symbol, the angel, stands as an emblem of self-determination and stoicism; in seeing the angel, Mary clings to her belief that her son survived and endures the pity of a society believing her to be grief-stricken and mentally unstable. Thus, in 'My Little Boy', Grossmann, like Schreiner, uses religious metaphors and symbols to legitimise women following their own beliefs, regardless of the social opprobrium that might bring.

\section{CONCLUSION}

The rediscovery of 'The Twin Brides of Waitotara' and 'My Little Boy' disrupts the prescribed view that Grossmann produced no fiction between her second novel, In Revolt (1893) and third novel, Knight of the Holy Ghost (1907). Although short stories, 'Twins' and 'Boy' explore themes also present in her longer texts. For example, the stories validate socially transgressive behaviour through religious discourse - a New Woman technique most associated with Olive Schreiner, a writer Grossmann admired. Similarly, 'Twins' also unpicks the rules and regulations controlling women's excursions into romance and, like New Women such as Sarah Grand, Grossmann questioned women's subjugated marital position. Thus the stories reveal how Grossmann continued to engage with political and literary developments during the fourteen years between the publication of In Revolt and Knight of the Holy Ghost, and they provide interesting and revealing glimpses of continued creativity.

\section{WORKS CITED}

Burns, Rebecca. 'Snapshot of a Life Reassessed: Edith Searle Grossmann'. Kotare: New Zealand Notes and Queries. 2009. Online. Accessed 30 Jan. 2010. http://www.nzetc.org/tm/scholarly/tei-BurSnap-t1-body.html

Christensen Nelson, Carolyn. British Women Fiction Writers of the 189os. New York: Twayne Publishers, 1996. 
---- 'Introduction'. A New Woman Reader: Fiction, Articles and Drama of the 189os. Ed. Carolyn Christensen Nelson. Peterborough, Ontario: Broadview Press, 2001. ix-xiv.

Cunningham, Gail. The New Woman and the Victorian Novel. New York: Barnes \& Noble Books, 1978.

Grand, Sarah. 'The New aspect of the Woman Question'. 1894. A New Woman Reader: Fiction, Articles and Drama of the 1890s. Ed. Carolyn Christensen Nelson. Peterborough, Ontario: Broadview Press, 2001. 141-146.

Grossmann, Edith Searle. In Revolt. London: Eden, Remington, 1893

---- 'Spare Half-Hours: Genius and Talent in the Colony'. Otago Witness 19 July 1894. Papers Past, online. Accessed 30 Jan. 2011. http://paperspast.natlib.govt.nz/cgi-bin/paperspast.

---- 'The Twin Brides of Waitotara'. Otago Witness 24 June 1897. Papers Past, online. Accessed 30 Jan. 2011. http://paperspast.natlib.govt.nz/cgibin/paperspast.

---- 'My Little Boy'. Otago Witness 2 Feb. 1899. Papers Past, online. Accessed 30 Jan. 2011. http://paperspast.natlib.govt.nz/cgi-bin/paperspast.

Heilmann, Ann. New Woman Strategies: Sarah Grand, Olive Schreiner, Mona Caird. Manchester and New York: Manchester University Press, 2004.

King James Bible. Online. Accessed 22 May 2011. http://www.kingjamesbibleonline.org.

Ledger, Sally. 'The New Woman and feminist fictions.' The Cambridge Companion to the Fin de Siècle. Ed. Gail Marshall. Cambridge: Cambridge University Press, 2007. Cambridge Collections Online. Accessed 30. Jan. 2011. http://cco.cambridge.org/public_home.

Moffat, Kirstine. 'Edith Searle Grossmann, 1863-1931'. Kotare 2007, Special Issue - Essays in New Zealand Literary Biography - Series One: 'Women Prose Writers to World War I'. Online. Accessed 30 Jan. 2011. http://www.nzetc.org/tm/scholarly/tei-Whio71Kota-t1-g1-t4.html

'Personal Notes from London'. Otago Witness, 25 Oct. 1906. Papers Past online. Accessed 31 Jan. 2011. http://paperspast.natlib.govt.nz/cgi-bin/paperspast

Pykett, Lyn. Engendering Fictions: The English Novel in the Early Twentieth Century. London: Edward Arnold, 1995.

Stubbs, Patricia. Women and Fiction: Feminism and the Novel 1880-1920. Bristol: The Harvester Press Ltd, 1979.

'Truth'. 21 Jan, 1893. Bicycles, Bangs and Bloomers: The New Woman in the Popular Press. Patricia Marks. Lexington, KY.: University Press of Kentucky, 1990. 


\section{ENDNOTES}

1. See the following for more details: Rebecca Burns, 'Snapshot of a Life Reassessd: Edith Searle Grossmann', 2009, Kotare: New Zealand Notes and Queries, online, accessed 31 Jan 2011. See http://www.nzetc.org/tm/scholarly/tei-BurSnap-t1body.html for more details.

2. The story may also have been republished in 1906; the Otago Witness of 25 Oct 1906 states 'Mrs Edith Searle Grossmann has a complete short story in the current issue of the Quiver [sic]. It is entitled 'The Twin Brides of Waitotara'. ('Personal Notes from London').

3. George Egerton, pen-name of Mary Dunne (1859-1945). As a writer of short stories, including Keynotes (1893), '[s]ex and sexual conflict are usually the core of Egerton's stories' (Stubbs, 110).

4. (1855-1920) South-African born writer. 